\title{
How Integrated is the 2013 Primary School Curriculum?
}

\author{
I Putu Mas Dewantara ${ }^{*}$, A. A. Gede Yudha Paramartha ${ }^{1}$ \\ ${ }^{1}$ Universitas Pendidikan Ganesha, Bali, Indonesia \\ *Corresponding author. Email: mas.dewantara@undiksha.ac.id
}

\begin{abstract}
The 2013 curriculum was developed on the basis of future thinking to prepare students for the challenges of the 21st century. At the primary school level, learning is carried out using an integrated thematic approach. This study aimed to answer how integrated the 2013 curriculum is. Therefore, this study described the integration of lesson content in (1) subject matter, (2) learning activity design, (3) learning assessment design, and (4) media design and learning resources. This research was a content analysis research using a quantitative descriptive approach. The data were collected from teacher and student books. The data collection method used was documentation. The data analysis technique was carried out according to the theory of Miles and Huberman (1992). The results showed that (1) there was an integrated learning content in the teaching material with a percentage of $92.42 \%$ which was categorized as very good and tended to be integrated in a multidisciplinary manner, (2) there was an integration of learning content in the design of the steps for learning activities with a percentage of $89.06 \%$ categorized as good and tended to be integrated intradisisciplinary, (3) there was an integrated learning content in the assessment design with a percentage of $91.84 \%$ in the very good category and tended to be integrated intradisisciplinary, and (4) there was an integration of lesson content in the design of media and learning resources with a percentage of $95.50 \%$ categorized as very good and tended to be integrated intradisisciplinary.
\end{abstract}

Keywords: Curriculum 2013, Elementary School, Integration of Lesson Content

\section{INTRODUCTION}

The 2013 curriculum was developed with the premise of future challenges, namely the challenges of the 21 st century marked by a knowledge-based society and future competencies. The 2013 curriculum promises the birth of productive, creative, innovative, and character human resources. With creativity, it is hoped that students will be able to innovate productively to be able to answer future challenges that are increasingly more complex. Providing 21st century skills to students are very important so that students are able to survive. The skills given must of course be in accordance with the values of the national characteristic and culture in order to create intelligent and character Indonesian people.

The 2013 curriculum was developed in the form of core competencies (KI) and basic competencies (KD). Core Competencies in the 2013 Curriculum consists of four interrelated dimensions. The four dimensions are spiritual attitude (KI 1), social attitude (KI 2), knowledge (KI 3), and skills (KI 4). At the primary school level, the four competencies are taught using an integrated thematic approach. Huber \& Hutching [1], Min, et al. [2], and John [3] explained that integrative thematic learning provides opportunities for students to connect their knowledge and experiences so that students understand more easily and are able to solve problems according to their needs and knowledge. Themes are a tool that unifies existing and diverse components of a variety of subject matter. Integrated thematic learning is defined as learning that is designed and packaged on certain themes, while the discussion is reviewed from various components and lesson content.

Basically, integrative thematic learning is a learning model for implementing an integrated curriculum (integrated curriculum approach). Integrated learning is learning based on an integrated curriculum approach that aims to create learning that is relevant and meaningful for students. In line with this, Novianti [4] explains that students are an important element in implementing the curriculum. Students are subjects who are directly involved in implementing the curriculum. The 
involvement and condition of students in learning activities must be considered directly. Elementary school children still need a lot of help and guidance from teachers in the learning process.

Schools must view education as a process of capacity building needed in the 21 st century. The International Commission on Education in the 21st Century which was formed by UNESCO stated that in this era of globalization, education is carried out with reference to the four pillars of education, namely learning to know, learning to do, learning to be, and learning to live together, then, Dantes [5] adds one more pillar, namely, learning to live sustainably, which means that students must understand the meaning of life. Thus, through this educational pillar, it is hoped that students will grow into complete individuals, be aware of all rights and obligations, and be able to master science and technology for provision and survival.

The implementation of the 2013 Curriculum in the learning process is an integrated thematic learning book, namely teacher books and student books published by the Indonesian Government. The subject matter that can be integrated is Indonesian, Civics, Mathematics, Natural Sciences (IPA), Social Sciences (IPS), Cultural Arts and Crafts (SBdP), and Physical Education, Sports and Health (PJOK). A learning can be said to be integrated if the learning component contains one or two lesson content with each facilitating indicators. Integration can also be said to exist if the learning component facilitates one of the lesson content and spiritual attitudes (KI 1) or social attitudes (KI 2).

The integration of the lesson content as an example can be seen from the existing material. The integration of teaching materials occurs when there is teaching material (in student books) that can be used in learning for more than one subject matter. For example, there is one text, it turns out that it contains material for learning purposes (TP) in Indonesian Language, Social Studies, and Science subjects. Material like this can be categorized as integrated material. But if one text is only used to reach $1 \mathrm{TP}$, or more than $1 \mathrm{TP}$ for the same subject matter (for example $2 \mathrm{TP}$ on Science) then the material is not included in the category of integrated material. Likewise, in terms of assessment. If in 2 assessment instruments (for example a rubric) it turns out that it is used to assess more than one subject matter (aspects that are assessed in the rubric include, for example, the content of Science and Social Sciences), the assessment is called integrated.

An integrated thematic learning book for elementary students has been prepared in the implementation of the 2013 Curriculum, the book has been reviewed by various parties under the coordination of the Ministry of Education and Culture. So far, there are still many questions and doubts regarding the integration of the lesson content in teacher handbooks and student books. In its implementation, the preliminary study shows that there is a lesson content that is not integrated, such as the learning component which only contains one lesson content with one facilitating indicator. What are the research findings that have been carried out so far?

Novianto \& Mustadi [6] found that (1) most of the indicators of integration were appropriate, (2) the scientific approach content was listed, (3) the authenthic assessment content had met most of the indicators, but still needed to be equipped with an assessment rubrics to help teachers. Trianingsih [7] found that when viewed from the material aspect, there was still a mismatch of activities with the theme, student cognitive development, and steps in the scientific approach. Suwandi \& Sari [8] and Ridwan \& Mudiono [9] examined the character content in textbooks. It was found that all indicators of nationalism were included in textbook learning materials. Nuraini [10] found that teacher books and student books have presented material by integrating cultural diversity in Indonesia.

Looking at the results of preliminary studies and studies that have been conducted by many researchers, it has not been fully described regarding the integration of the lesson content. Therefore, a study that is able to provide a more comprehensive and in-depth description of the prototype of the integration is needed. This study aimed to provide an overview of the extent to which the integration of the subject matter in learning materials, the design of learning activities, the design of the assessment, and the design of media and resources.

\section{RESEARCH METHODS}

\subsection{Research Design}

This research was a content analysis research using a qualitative descriptive approach. This study aimed to describe the integration of the lesson content in the teacher and student handbooks in the 2013 Curriculum.

\subsection{Data and Data Sources}

The data from this study are all data related to the integration of the curriculum 2013 primary school lesson content in teacher books and student books. The data sources in this study were the teacher's books and the 2013 Curriculum student books for grades I and III. The choice of book theme is done randomly.

\subsection{Data Collection Methods and Instruments}

The data from this study are all data related to the The method used was documentation with an instrument in the form of a checklist. The documents needed in this study were the teacher's book and student's book which were used to analyze the integration of the lesson content in the four learning components. 


\subsection{Data Analysis Method}

Data analysis in this study followed the four stages proposed by Miles and Huberman [11], namely data collection, data reduction, data presentation, and drawing conclusions/verification. The determination of the category of lesson content integration follows the conversion in Table 1 below.

Table 1. Categories of Lesson Content Integration

\begin{tabular}{|c|c|}
$\begin{array}{c}\text { Percentage of Achievement } \\
(\%)\end{array}$ & Category \\
\hline $90-100$ & Very Good \\
\hline $80-89$ & Good \\
\hline $65-79$ & Moderate \\
\hline $40-64$ & Low \\
\hline $00-39$ & Very Low \\
\hline
\end{tabular}

\section{RESULTS AND DISCUSSION}

\subsection{Result}

As explained in the research methods section, the data for this study came from the 2013 Curriculum teacher and student books, namely the Grade I and teacher student book with the theme Clean, Healthy and Beautiful Environment (hereinafter referred to as Book A) and the Grade III student and teacher book with the theme Energy and Beautiful Change (hereinafter referred to as Book B). These two books were selected randomly to see the integration of the lesson content in the 2013 primary school curriculum. The Grade I student and teacher book with the theme Clean, Healthy and Beautiful Environment consisted of 24 lessons and the Grade III student and teacher book on the theme of Energy and Change also consisted of 24 lessons. The following is a table of analysis of the integration of learning content.

Table 2. Results of the Analysis of the Integration of Subject Content in Subject Materials

\begin{tabular}{|c|c|c|c|c|c|c|}
\hline \multirow{3}{*}{ Learning To- } & \multicolumn{3}{|c|}{ Book A } & \multicolumn{3}{|c|}{ Book B } \\
\hline & \multicolumn{3}{|c|}{ Integration Classification } & \multicolumn{3}{|c|}{ Integration Classification } \\
\hline & $\begin{array}{c}\text { No } \\
\text { Integration }\end{array}$ & $\begin{array}{l}\text { Intradisisciplinary } \\
\text { Integration }\end{array}$ & $\begin{array}{l}\text { Multidisciplinary } \\
\text { Integration }\end{array}$ & $\begin{array}{c}\text { No } \\
\text { Integration }\end{array}$ & $\begin{array}{l}\text { Intradisisciplinary } \\
\text { Integration }\end{array}$ & $\begin{array}{l}\text { Multidisciplinary } \\
\text { Integration }\end{array}$ \\
\hline 1 & 1 & 1 & 2 & 1 & 1 & 2 \\
\hline 2 & 0 & 2 & 2 & 1 & 0 & 2 \\
\hline 3 & 0 & 0 & 2 & 0 & 2 & 1 \\
\hline 4 & 0 & 0 & 2 & 0 & 1 & 2 \\
\hline 5 & 0 & 1 & 1 & 0 & 2 & 1 \\
\hline 6 & 0 & 1 & 0 & 0 & 0 & 1 \\
\hline 7 & 0 & 0 & 2 & 1 & 2 & 0 \\
\hline 8 & 0 & 2 & 2 & 0 & 1 & 3 \\
\hline 9 & 0 & 0 & 1 & 0 & 2 & 1 \\
\hline 10 & 1 & 3 & 2 & 1 & 1 & 2 \\
\hline 11 & 0 & 0 & 0 & 1 & 1 & 1 \\
\hline 12 & 0 & 1 & 0 & 0 & 2 & 1 \\
\hline 13 & 0 & 2 & 1 & 0 & 3 & 1 \\
\hline 14 & 0 & 0 & 1 & 0 & 2 & 2 \\
\hline 15 & 0 & 2 & 1 & 0 & 2 & 1 \\
\hline 16 & 0 & 2 & 1 & 0 & 1 & 2 \\
\hline 17 & 0 & 1 & 1 & 0 & 0 & 3 \\
\hline 18 & 0 & 2 & 0 & 0 & 1 & 2 \\
\hline 19 & 0 & 1 & 2 & 1 & 2 & 1 \\
\hline 20 & 0 & 1 & 1 & 0 & 1 & 2 \\
\hline 21 & 0 & 1 & 2 & 0 & 1 & 1 \\
\hline 22 & 0 & 0 & 4 & 1 & 0 & 3 \\
\hline 23 & 1 & 0 & 0 & 0 & 0 & 3 \\
\hline 24 & 0 & 1 & 1 & 0 & 1 & 1 \\
\hline Total & 3 & 24 & 31 & 7 & 28 & 39 \\
\hline
\end{tabular}


Table 2. shows that in Book A there are 3 teaching materials that did not contain integration, namely on subject matter 1, 10, and 23. There were 24 interdisciplinary integration and 31 multidisciplinary integration. While in Book B there were 7 subject matter that did not contain integration, namely material $1,2,6$, $7,10,11,19$, and 22 . There were 28 intradisciplinary integrations and 39 subject matters which were integrated multidisciplinary.

Table 3. The Analysis of Learning Activities Design Integration

\begin{tabular}{|c|c|c|c|c|c|c|}
\hline \multirow{3}{*}{$\begin{array}{l}\text { Learning } \\
\text { To- }\end{array}$} & \multicolumn{3}{|c|}{ Book A } & \multicolumn{3}{|c|}{ Book B } \\
\hline & \multicolumn{3}{|c|}{ Integration Classification } & \multicolumn{3}{|c|}{ Integration Classification } \\
\hline & $\begin{array}{c}\text { No } \\
\text { Integration }\end{array}$ & $\begin{array}{l}\text { Intradisisciplinary } \\
\text { Integration }\end{array}$ & $\begin{array}{l}\text { Multidisciplinary } \\
\text { Integration }\end{array}$ & $\begin{array}{c}\text { No } \\
\text { Integration }\end{array}$ & $\begin{array}{l}\text { Intradisisciplinary } \\
\text { Integration }\end{array}$ & $\begin{array}{l}\text { Multidisciplinary } \\
\text { Integration }\end{array}$ \\
\hline 1 & 0 & 4 & 0 & 0 & 3 & 2 \\
\hline 2 & 1 & 2 & 0 & 0 & 3 & 2 \\
\hline 3 & 0 & 0 & 4 & 0 & 3 & 1 \\
\hline 4 & 0 & 3 & 0 & 0 & 3 & 1 \\
\hline 5 & 0 & 2 & 0 & 0 & 2 & 1 \\
\hline 6 & 1 & 2 & 0 & 1 & 1 & 1 \\
\hline 7 & 1 & 6 & 0 & 1 & 3 & 1 \\
\hline 8 & 0 & 3 & 0 & 1 & 1 & 3 \\
\hline 9 & 1 & 4 & 0 & 0 & 2 & 1 \\
\hline 10 & 1 & 6 & 0 & 0 & 2 & 2 \\
\hline 11 & 0 & 3 & 0 & 0 & 2 & 1 \\
\hline 12 & 1 & 3 & 0 & 0 & 2 & 1 \\
\hline 13 & 1 & 4 & 0 & 1 & 2 & 1 \\
\hline 14 & 0 & 2 & 0 & 0 & 1 & 4 \\
\hline 15 & 0 & 3 & 0 & 0 & 2 & 1 \\
\hline 16 & 0 & 3 & 0 & 0 & 4 & 1 \\
\hline 17 & 0 & 2 & 0 & 0 & 0 & 4 \\
\hline 18 & 1 & 0 & 1 & 1 & 1 & 3 \\
\hline 19 & 1 & 5 & 0 & 0 & 3 & 2 \\
\hline 20 & 1 & 3 & 0 & 0 & 1 & 3 \\
\hline 21 & 1 & 5 & 0 & 0 & 1 & 2 \\
\hline 22 & 3 & 4 & 0 & 0 & 0 & 4 \\
\hline 23 & 1 & 2 & 0 & 0 & 0 & 3 \\
\hline 24 & 1 & 5 & 0 & 0 & 1 & 2 \\
\hline Total & 16 & 76 & 5 & 5 & 43 & 47 \\
\hline
\end{tabular}

Table 3. shows that in Book A the design of nonintegrated learning steps were 16 in total, 76 intradisisciplinary integrated, and 5 were multidisciplinary integrated learning design. In Book B, there are 5 steps that were not integrated, 43 intradisisciplinary integrated and 47 multidisciplinary integrated learning activities. 
Table 4. Results of the Assessment Design Integration Analysis

\begin{tabular}{|c|c|c|c|c|c|c|}
\hline \multirow{3}{*}{$\begin{array}{l}\text { Learning } \\
\text { To- }\end{array}$} & \multicolumn{3}{|c|}{ Book A } & \multicolumn{3}{|c|}{ Book B } \\
\hline & \multicolumn{3}{|c|}{ Integration Classification } & \multicolumn{3}{|c|}{ Integration Classification } \\
\hline & $\begin{array}{c}\text { No } \\
\text { Integration }\end{array}$ & $\begin{array}{l}\text { Intradisisciplinary } \\
\text { Integration }\end{array}$ & $\begin{array}{l}\text { Multidisciplinary } \\
\text { Integration }\end{array}$ & $\begin{array}{c}\text { No } \\
\text { Integration }\end{array}$ & $\begin{array}{l}\text { Intradisisciplinary } \\
\text { Integration }\end{array}$ & $\begin{array}{c}\text { Multidisciplinary } \\
\text { Integration }\end{array}$ \\
\hline 1 & 1 & 4 & 0 & 2 & 2 & 0 \\
\hline 2 & 0 & 2 & 0 & 0 & 3 & 0 \\
\hline 3 & 0 & 1 & 1 & 0 & 3 & 0 \\
\hline 4 & 0 & 2 & 0 & 2 & 2 & 0 \\
\hline 5 & 0 & 2 & 0 & 0 & 4 & 0 \\
\hline 6 & 0 & 3 & 0 & 1 & 2 & 0 \\
\hline 7 & 0 & 4 & 0 & 0 & 3 & 0 \\
\hline 8 & 0 & 2 & 0 & 0 & 3 & 0 \\
\hline 9 & 1 & 4 & 0 & 0 & 3 & 0 \\
\hline 10 & 0 & 3 & 0 & 0 & 3 & 0 \\
\hline 11 & 1 & 3 & 0 & 2 & 2 & 0 \\
\hline 12 & 0 & 3 & 0 & 0 & 3 & 0 \\
\hline 13 & 0 & 5 & 0 & 0 & 3 & 0 \\
\hline 14 & 0 & 2 & 0 & 0 & 3 & 0 \\
\hline 15 & 0 & 4 & 0 & 0 & 2 & 0 \\
\hline 16 & 0 & 3 & 0 & 0 & 3 & 0 \\
\hline 17 & 0 & 2 & 0 & 0 & 2 & 0 \\
\hline 18 & 0 & 3 & 0 & 0 & 3 & 0 \\
\hline 19 & 0 & 3 & 0 & 0 & 3 & 0 \\
\hline 20 & 0 & 2 & 0 & 0 & 3 & 0 \\
\hline 21 & 0 & 3 & 0 & 0 & 3 & 0 \\
\hline 22 & 0 & 3 & 0 & 2 & 2 & 0 \\
\hline 23 & 0 & 2 & 0 & 0 & 3 & 0 \\
\hline 24 & 0 & 3 & 0 & 0 & 3 & 0 \\
\hline Total & 3 & 68 & 1 & 9 & 66 & 0 \\
\hline
\end{tabular}

Table 4. shows the results of the analysis of the integration of the learning assessment design. From the results of the analysis it was found that in Book A there were 3 assessment designs that were not integrated, 68 intradisisciplinary integrated assessment designs and 1 multicultural integrated assessment design. In Book B, there are 9 assessment designs that were not integrated, 66 assessment designs were intradisisciplinary integrated, and there was no multicultural integrated assessment design.

Table 5. Results of the Analysis of Integration of Media Design and Learning Resources

\begin{tabular}{|c|c|c|c|c|c|c|}
\hline \multirow{2}{*}{\begin{tabular}{c}
\multirow{2}{*}{ Learning } \\
To-
\end{tabular}} & \multicolumn{2}{|c|}{ Book A } & \multicolumn{3}{c|}{ Book B } \\
\cline { 2 - 7 } & No Integration & $\begin{array}{c}\text { Intradisisciplinary } \\
\text { Integration }\end{array}$ & $\begin{array}{c}\text { Multidisciplinary } \\
\text { Integration }\end{array}$ & No Integration & $\begin{array}{c}\text { Intradisisciplinary } \\
\text { Integration }\end{array}$ & $\begin{array}{c}\text { Multidisciplinary } \\
\text { Integration }\end{array}$ \\
\hline 1 & 1 & 1 & 0 & 0 & 3 & 2 \\
\hline 2 & 1 & 1 & 0 & 0 & 3 & 0 \\
\hline
\end{tabular}




\begin{tabular}{|c|c|c|c|c|c|c|}
\hline \multirow{3}{*}{$\begin{array}{l}\text { Learning } \\
\text { To- }\end{array}$} & \multicolumn{3}{|c|}{ Book A } & \multicolumn{3}{|c|}{ Book B } \\
\hline & \multicolumn{3}{|c|}{ Integration Classification } & \multicolumn{3}{|c|}{ Integration Classification } \\
\hline & No Integration & $\begin{array}{l}\text { Intradisisciplinary } \\
\text { Integration }\end{array}$ & $\begin{array}{l}\text { Multidisciplinary } \\
\text { Integration }\end{array}$ & No Integration & $\begin{array}{l}\text { Intradisisciplinary } \\
\text { Integration }\end{array}$ & $\begin{array}{l}\text { Multidisciplinary } \\
\text { Integration }\end{array}$ \\
\hline 3 & 0 & 0 & 1 & 0 & 3 & 0 \\
\hline 4 & 0 & 1 & 0 & 0 & 1 & 1 \\
\hline 5 & 0 & 1 & 0 & 0 & 1 & 0 \\
\hline 6 & 0 & 0 & 0 & 1 & 2 & 0 \\
\hline 7 & 1 & 2 & 0 & 0 & 3 & 0 \\
\hline 8 & 0 & 2 & 0 & 0 & 3 & 0 \\
\hline 9 & 1 & 2 & 0 & 0 & 3 & 0 \\
\hline 10 & 0 & 2 & 0 & 0 & 2 & 1 \\
\hline 11 & 0 & 1 & 0 & 0 & 2 & 1 \\
\hline 12 & 0 & 2 & 0 & 0 & 3 & 1 \\
\hline 13 & 0 & 3 & 0 & 0 & 3 & 0 \\
\hline 14 & 0 & 1 & 0 & 0 & 3 & 0 \\
\hline 15 & 0 & 2 & 0 & 0 & 1 & 1 \\
\hline 16 & 0 & 1 & 0 & 0 & 4 & 1 \\
\hline 17 & 0 & 2 & 0 & 0 & 3 & 0 \\
\hline 18 & 0 & 0 & 1 & 0 & 3 & 0 \\
\hline 19 & 0 & 1 & 0 & 0 & 1 & 1 \\
\hline 20 & 0 & 2 & 0 & 0 & 1 & 2 \\
\hline 21 & 0 & 2 & 0 & 0 & 3 & 0 \\
\hline 22 & 0 & 2 & 0 & 0 & 1 & 2 \\
\hline 23 & 0 & 1 & 0 & 0 & 1 & 2 \\
\hline 24 & 0 & 1 & 0 & 0 & 2 & 1 \\
\hline Total & 4 & 33 & 2 & 1 & 55 & 16 \\
\hline
\end{tabular}

Table 5. shows that in Book A there are 4 designs of media and learning resources that did not contain integration, 33 media and learning resources designs were intradisisciplinary integrated, and 2 learning media and learning resources designs were multidisciplinary integrated. In Book B, there was one media design and learning resources that was not integrated, 55 media and learning resources designs were integrated intradisisciplinary, and 16 learning media and learning resources designs were multidisciplinary integrated.

Recapitulation of the results of data analysis related to the integration of lesson content in (1) learning materials, (2) design of learning activity steps, (3) assessment design, and (4) media design and learning resources are shown in Table 6 below.

Table 6. Recapitulation of Results of Integration Analysis of Lessons

\begin{tabular}{|c|c|c|c|c|}
\hline \multirow{2}{*}{\multicolumn{2}{c|}{ Learning Components }} & \multicolumn{3}{|c|}{ Integration Classification } \\
\cline { 2 - 5 } & $\begin{array}{c}\text { There is no } \\
\text { integration }\end{array}$ & $\begin{array}{c}\text { Intradisisciplinary } \\
\text { Integration }\end{array}$ & $\begin{array}{c}\text { Multidisciplinary } \\
\text { Integration }\end{array}$ & $\begin{array}{c}\text { Total } \\
(\%)\end{array}$ \\
\hline Learning materials & 10 & 52 & 70 & 92,42 \\
\hline Design of Learning Activity Steps & 21 & 119 & 1 & 89,06 \\
\hline Assessment Design & 12 & 134 & 18 & 91,84 \\
\hline Media Design and Learning Resources & 5 & 88 & 141 & 95,50 \\
\hline TOTAL & 48 & 393 & 91,75 \\
\hline
\end{tabular}


Based on the results of the analysis of the integration of lesson content on the four learning components in Table 6 , it was found that 48 were classified as no integration, 393 were classified as intradisisciplinary integration and 141 were classified as multidisciplinary integration. So, it can be concluded that the classification of the integration of lesson content on the four components of learning in the teacher's book and elementary school student books as a whole, namely intradisisciplinary integration has a percentage of $91.75 \%$ in the very good category.

\subsection{Discussion}

The results of the analysis in Table 2, namely the first analysis shows that there was an integration of the subject matter in the learning material. The results showed that there was an integration of subject matter in elementary school learning materials with the classification of multidisciplinary integration having a percentage of $92.42 \%$ in the very good category. The results of this study describe the content of learning material in student books was very well in implementing integrated thematic learning. This finding is in line with the opinion of Majid saying that integrated thematic learning is integrated learning using themes to link various subject matter to learning material to provide a meaningful and contextual experience for students [12]. The subject matter has been developed according to existing objectives. This finding is in line with the opinion of Ernawati [13] and Fadlilah [14] that the material contained in textbooks should be material that is arranged in relation to one another into a single unit and does not deviate from the objectives of the teaching.

Integration of lesson content is a way so that subject matter can be understood by students. This is in line with the opinion of Yusnawarni [15] that elementary students are still not able to understand the concept of lesson content if it is given partially or separately. What is interesting about these findings is that multidisciplinary integration in elementary school learning materials always involves Indonesian language content with other subject content, so that Indonesian language learning content can be said to be an opening for integration and used as a carrier of knowledge in the 2013 curriculum. Zabadi [16] explains that the role of Indonesian is very central because it has to be in front of all other subjects.

The integration of existing lesson content as illustrated by this study should also be supported by the ability of teachers to manage learning material. Success in implementing integrated thematic learning depends on knowledge, understanding, and creativity in managing learning material. The more complete the learning material and the wider the understanding, the better the delivery, and implementation of learning. This is supported by [17] which states that if the learning material has been collected, the next step is to sort, classify, and arrange it into indicators of basic competencies, then learn about the content of the learning material. Through this, it can provide benefits for teachers so that they are able to encourage student involvement in an active and fun way; not only for students to know (learning to know) but also to do (learning to do), to be (learning to be), and to live together (learning to live together), as well as holistic and authentic with the aim of implementing integrated thematic learning.

The results of the second analysis show that there is an integrated learning content in the design of the steps for elementary school learning activities with the intradisisciplinary integration classification having a percentage of $89.06 \%$ in the good category. The steps of learning activities presented in the teacher's book and student's book have integrated attitude competencies, skills competencies, and knowledge competencies in each learning process. This makes learning a complete unit from one lesson content through various activities. This is in accordance with the Process Standards in the 2013 Curriculum using a scientific approach, which includes observing, questioning, gathering information, reasoning, and communicating in learning activities. This finding is in line with the opinion of Novianto [6] that the scientific approach content listed in the textbook includes various activities that direct students to interact with the environment in developing knowledge.

The results showed that the learning steps were designed to provide learning opportunities individually and in groups. This finding is in line with the opinion of Huber \& Hutchings [1] regarding integrated thematic learning (integrated instruction) which allows students, both individually and in groups to carry out various activities aimed at finding learning concepts. This is also in line with Daryanto's [18] explanation that usually learning activities contain elements: (1) a description of what will be studied, (2) discussion and exchange of ideas, (3) activities that use various instructional tools, laboratories, and others, (4) activities within the school environment, such as visits, fieldwork, exploration and research, (5) activities with various sources, such as library books, audio-visual tools, and others, (6) creative activities , such as drama, fine arts, music, handwork and so on.

Learning that activates students according to Mehl, Mills, \& Douglass [19] is learning which includes activities in the nervous system such as seeing, hearing, smelling, feeling, thinking, physical or motor activity. Students are actively involved in learning activities whether information skills, understanding, habits, ideal things, attitudes, interests, or related to the nature of the task. The component of the design of learning steps has shown activities as well as existing theories. Therefore 
the components of the design of the steps for learning activities in the teacher's and student's books are good and can be implemented in elementary schools.

The results of the third analysis show that there is an integrated learning content in the assessment design with an intradisisciplinary integration classification of $91.84 \%$ in the very good category. The findings indicate that process assessment is an integrated attitude assessment on the observed aspects of the attitude. In the assessment of results, the knowledge aspect is seen from the form of the test used. The test used for the cognitive realm is in the form of a written test that uses question words that describe answers, for example how and why. In the skills aspect, it can be seen from the assessment rubric used, for example skills (a) reading the results of the work, (b) discussion, and (c) making products.

The assessment instrument developed in the teacher's book and student's book has been designed to measure the achievement of the learning material and the design of the steps for the learning activities developed. The analysis of the teacher's and student's books shows that the existing assessment instruments are only able to facilitate the the assessment of learning objectives on one subject only. This is in line with the Ministry of Education and Culture's statement (Technical Guide for Assessment in SD Curriculum 2013) that authentic assessment is an assessment that is carried out broadly, completely and thoroughly to be able to assess aspects of attitudes, knowledge and skills starting from input, process, arrived at the learning output. This is also in line with the opinion of Hernawan, et al. [20] which states that the object in integrated thematic learning assessment (integration) includes the assessment of the learning process, namely the effort to give value to learning activities carried out by teachers and students, while the assessment of learning outcomes, namely the process of giving value to the learning outcomes achieved by using certain criteria (learning objectives).

Assessment for knowledge is assessed through written tests, oral tests, and assignments. Meanwhile, assessment for skill is assessed through performance equipped with a rubric. In line with Prastowo's opinion [21] that authentic assessment is a type of assessment that accommodates measurement of all aspects that should be measured in the learning process both in the aspects of attitude competence, skill competence, and knowledge competence. It is also in line with Kunandar [22] that the assessment of student learning outcomes (using authentic assessment) covers the competence of attitudes, knowledge, and skills that are carried out in a balanced manner so that they can be used to determine the relative position of each student against the predetermined standards. Thus, the components of the assessment in the teacher's book and student's book are good and can be implemented in learning in elementary schools.
The results of the fourth analysis show that there is an integration of lesson content in the design of media and learning resources. The results showed that the integration of lesson content in the design of media and learning resources in teacher books and elementary school student books was intradisisciplinary integration with a percentage of $95.50 \%$ in the very good category. The results of this study describe integrated thematic learning in teacher books and student books that have implemented media design and learning resources very well with intradisisciplinary integration which is the main learning resource for teachers and students.

In the media and learning resources in the teacher's and student's books, it is found that there are pictures, text, rhythmic musical instruments, VCDs, concrete objects and the environment used to make it easier for students to master the learning material. In addition, with the media and learning resources, learning will be more attractive to students. In line with Prastowo [21] that media and learning resources are a component of a learning system that includes messages, people, materials, technical tools and the environment that can affect student learning outcomes. It is also in line with the opinion of Crismono [23] that the use of the environment as a contextual learning resource can enrich students' insights because they learn and experience it firsthand. Arsyad [24] also argues that media is a component of learning resources that contains additional material according to the student's environment that can stimulate learning.

Intradisciplinary integration is more dominant than multidisciplinary integration because the use of media and learning resources is not integrated but in accordance with the learning objectives of the subject matter. Sudjana and Sudjana \& Rivai [25] state that there are two criteria for selecting media and learning sources, namely general criteria and specific criteria that are in accordance with the needs and conditions of the learning objectives of the subject matter to be achieved. By using these criteria, the selection of media and learning resources will be easier, more effective and efficient.

\section{CONCLUSION}

It can be concluded that the classification of the integration of lesson content on the four components of learning in the teacher's book and elementary school student books as a whole, namely intradisisciplinary integration has a percentage of $91.75 \%$ which is categorized as very good. The results showed that (1) there was an integrated learning content in the teaching material with a percentage of $92.42 \%$ categorized as very good and tended to be integrated in a multidisciplinary manner, (2) there was an integration of learning content in the design of learning activity steps with a percentage of $89.06 \%$ in good category and tended to be integrated intradisisciplinary, (3) there was an integrated learning 
content in the assessment design with a percentage of $91.84 \%$ in the very good category and tended to be integrated intradisisciplinary, and (4) there was an integration of lesson content in the design of media and learning resources with a percentage of $95.50 \%$ categorized as very good and tended to be integrated intradisisciplinary.

\section{REFERENCES}

[1] M. T. Huber and P. Hutchings, Integrative Learning: Mapping the terrain, Carnegie Found, 2004, pp. 1-32.

[2] K. C. Min, A. M. Rashid, and M. I. Nazri, Teachers Understanding And Practice Towards Thematic Approach In Teaching Integrated Living Skills (ils) In Malaysia, Int. J. Humanit. Soc. Sci., vol. 2, no. 23, 2012.

[3] Y. J. John, A 'New' Thematic, Integrated Curriculum for Primary Schools of Trinidad and Tobago: A Paradigm Shift, Int. J. High. Educ., vol. 4, no. 3, 2015, pp. 172-187. Doi: 10.5430/ijhe.v4n3p172.

[4] A. Noviatmi, Evaluasi Implementasi Kurikulum 2013 Kelas I \& IV SD di Kabupaten Magelang Tahun Pelajaran 2014/2015, Universitas Negeri Yogyakarta, 2015.

[5] N. Dantes, Pedagogik Dalam Perspektif, Singaraja: Undiksha Press, 2017.

[6] A. Novianto and A. Mustadi, Analisis Buku Teks Muatan Tematik Integratif, Scientific Approach, Dan Authentic Assessment Sekolah Dasar, J. Kependidikan Penelit. Inov. Pembelajaran, vol. 45, no. 1, p. 109685, 2015. Doi: 10.21831/jk.v45i1.7181.

[7] R. Trianingsih, Analisis Buku Kelas V Sd/Mi Kurikulum 2013 Pada Tema Kerukunan Dalam Bermasyarakat, Ar-Risalah, vol. 17, no. 1, 2016, pp. 25-39.

[8] I. K. Suwandi and I. P. Sari, Analisis Karakter Nasionalisme Pada Buku Teks Kurikulum 2013 Edisi Revisi 2016 Kelas 1 SD, Elem. Sch., vol. 4, no. 2, 2017, pp. 152, [Online]. Available: https://journal.upy.ac.id/index.php/es/article/view/ 174.

[9] M. H. Ridwan and A. Mudiono, Analisis Muatan Nilai-Nilai Karakter pada Buku Siswa Kelas IV Sekolah Dasar Tema Indahnya Kebersamaan, Wahana Sekol. Dasar, vol. 25, no. 1, 2017, pp. 1-7. Doi: 10.17977/um035v25i12017p001.

[10] L. Nuraini, Integrasi Nilai Kearifan Lokal Dalam Pembelajaran Matematika Sd/Mi Kurikulum 2013,
J. Pendidik. Mat., vol. 1, no. 2, 2019. Doi: 10.21043/jpm.v1i2.4873.

[11] M. B. Miles and A. M. Huberman, Qualitative data analysis: An expanded sourcebook, Sage, 1994.

[12] A. Majid, Pembelajaran Tematik Terpadu, Bandung: PT. Remaja Rosdakarya, 2014.

[13] Y. Ernawati, Telaah Buku Teks Tematik Terpadu Kelas Iv Sd Kurikulum 2013, J. Ilm. Bina Edukasi, vol. 11, no. 2, 2019, pp. 109-123. Doi: 10.33557/jedukasi.v11i2.223.

[14] M. Fadillah, Implementasi Kurikulum 2013, Yogyakarta: Ar-Ruzz Media, 2014.

[15] Y. Yusnawarni, Peran Bahasa Indonesia dalam Pembelajaran Tematik Terpadu melalui Pendekatan Saintifik, Madah, vol. 5, no. 2, 2017.

[16] F. Zabadi, Seminar Kebahasaan Sempena Sidang Ke-54 Mabbim, Brunei 1, 2010, pp. 1-14.

[17] Trianto, Desain Pengembangan Pembelajaran Tematik Bagi Anak Usia Dini TK/RA Dan Anak Usia Awal SD/MI, Jakarta: Kencana Prenada Media Group, 2013.

[18] Daryanto, Pembelajaran Tematik, Terpadu, Terintegrasi (Kurikulum 2013), Yogyakarta: Gava Media, 2014.

[19] O. Hamalik, Perencanaan Pengajaran Berdasarkan Pendekatan Sistem, Jakarta: Bumi Aksara, 2017.

[20] A. H. Hernawan, R. Susilana, S. Julaeha, and W. Sanjaya, Pengembangan kurikulum dan pembelajaran, Jakarta: Universitas Terbuka, 2011.

[21] Prastowo, Analisis Pembelajaran Tematik Terpadu, Jakarta: Prenadamedia Group, 2019.

[22] Kunandar, Penilaian Autentik (Penilaian Hasil Belajar Peserta Didik berdasarkan Kurikulum 2013), Jakarta: Raja Grafindo Persada, 2013.

[23] P. C. Crismono, Penggunaan Media Dan Sumber Belajar Dari Alam Sekitar Dalam Pembelajaran Matematika, J. Gammath, vol. 2, no. 2, 2017, pp. 72-77.

[24] A. Arsyad, Media Pembelajaran, Jakarta: Rajawali Press, 2009.

[25] N. Sudjana and A. Rivai, Media Pembelajaran, Jakarta: Sinar Baru Algensindo Offset, 2010. 